\title{
Ectoparasites of Nile tilapia (Oreochromis niloticus) in cage farming in a hydroelectric reservoir in Brazil
}

\author{
Ectoparasitas de tilápias-do-Nilo (Oreochromis niloticus) criadas em tanques-rede em \\ um reservatório de usina hidrelétrica no Brasil \\ Aline Cristina Zago ${ }^{1 *}$; Lidiane Franceschini ${ }^{1}$; Fabiana Garcia²; Sérgio Henrique Canello Schalch²; \\ Kátia Suemi Gozi²; Reinaldo José da Silva ${ }^{1}$
}

\begin{abstract}
${ }^{1}$ Departamento de Parasitologia, Instituto de Biociências, Universidade Estadual Paulista - UNESP, Botucatu, SP, Brasil
${ }^{2}$ Agência Paulista de Tecnologia dos Agronegócios - APTA, Secretaria de Agricultura e Abastecimento, Polo Regional do Noroeste Paulista, Votuporanga, SP, Brasil
\end{abstract}

Received November 28, 2013

Accepted May 8, 2014

\begin{abstract}
For this study, we performed a parasitological analysis of cage-cultured Nile tilapia (Oreochromis niloticus) from the Água Vermelha Reservoir, Southeastern Brazil, and verified relationships with limnological data, seasonality, and fish growth phase. From March 2010 to March 2011, sixty-three specimens of O. niloticus in three growth phases (i.e., initial, intermediate, and final) were collected. All fish specimens were infested with at least one ectoparasite species (prevalence $=100 \%$ ). Five species of protozoans (Trichodina compacta, Trichodina magna, Ichthyophthirius multifliis, Piscinoodinium pillulare, and Epistylis sp.) and five species of monogenoids (Cichlidogyrus halli, Cichlidogyrus thurstonae, Cichlidogyrus sp. 1, Scutogyrus longicornis, and Gyrodactylus sp.) were observed. The abundance of Trichodina spp. and the prevalence of Epistylis sp. were higher in the dry season, and the prevalence of $C$. halli was higher in the rainy season. For the majority of ectoparasites found in this study, fish in the intermediate and final phases had higher parasitism rates than those in the initial phase. The data presented may help fish farmers to understand the parasite dynamics of the fish species studied in cage-farming systems.
\end{abstract}

Keywords: Fish farming, health, water quality, monogenoid, Trichodina spp., Ichthyophthirius multifliis.

\section{Resumo}

O presente estudo teve como objetivo realizar análise parasitológica de tilápias-do-Nilo, (Oreochromis niloticus) criadas em tanques-rede no Reservatório de Água Vermelha, Sudeste do Brasil, bem como verificar suas inter-relaçôes com as características limnológicas, sazonalidade e fase de criação. Durante o período de março de 2010 a março de 2011, espécimes de $O$. niloticus, pertencentes a três fases de criação (inicial, intermediária e final), foram colhidos, totalizando 63 indivíduos. Todos os peixes estavam infestados por pelo menos uma espécie de ectoparasita (prevalência $=100 \%$ ). Foi observada a ocorrência de cinco espécies de protozoários (Trichodina compacta, Trichodina magna, Ichthyophthirius multifiliis, Piscinoodinium pillulare e Epistylis sp.), assim como cinco espécies de monogenóides (Cichlidogyrus halli, Cichlidogyrus thurstonae, Cichlidogyrus sp. 1, Scutogyrus longicornis e Gyrodactylus sp.). A abundância de Trichodina spp. e prevalência de Epistylis sp. foram maiores no período seco, e a prevalência de $C$. halli foi maior no período chuvoso. Para a maioria dos ectoparasitas encontrados neste estudo, os peixes pertencentes às fases intermediária e final apresentaram maiores taxas de parasitismo do que aqueles pertencentes à fase inicial. Os dados apresentados neste estudo podem ser de grande importância para piscicultores, de forma a auxiliá-los no conhecimento da dinâmica dos parasitas da espécie de peixe estudada em sistemas de tanques-rede.

Palavras-chave: Piscicultura, sanidade, qualidade da água, monogenóide, Trichodina spp., Ichthyophthirius multifiliis.

\footnotetext{
*Corresponding author: Aline Cristina Zago

Departamento de Parasitologia, Instituto de Biociências, Universidade Estadual

Paulista - UNESP, Campus de Botucatu, Distrito de Rubião Junior, s/n,

CEP 18618-970, Botucatu, SP, Brasil

e-mail: alinecristhina@yahoo.com.br
} 


\section{Introduction}

Fish farming is an important activity for the production of protein for human consumption. Brazil is ranked internationally as a country with high potential for fish farming because of its extensive territory and climatic conditions that favor the implementation of freshwater fish culture (PAVANELLI et al., 2008). Fish cage technology is widespread in Brazil, since a production system employing it can use already-existing water resources and requires less investment than traditional aquaculture in fish ponds (ONO; KUBITZA, 1999).

In intensive fish farms, such as cage-culture systems, problems associated with nutritional deficiency, inadequate handling, and poor water quality are common. The stressful conditions caused by these factors can foster infectious and parasitic diseases (CAVICHIOLO et al., 2002; MARTINS et al., 2002). Thus, studies on parasites and other pathogens of aquatic organisms are extremely important for the creation of the species with potential for aquaculture.

The Nile tilapia, Oreochromis niloticus (Linnaeus, 1758), is a widely farmed fish species that is used as an economic source in Brazil (LIZAMA et al., 2007). Several diseases and parasites can affect $O$. niloticus production; however, certain parasites frequently parasitize this fish species, including the protozoan ciliates Trichodina spp. Ehrenberg, 1830, Ichthyophthirius multifiliis (Fouquet, 1876), and monogenoids (MARTINS et al., 2011).

Monogenoids are considered to be responsible for the most important parasitic disease in Brazilian fish farming because they can cause high mortality rates. The presence of these parasites in fish gills can cause hypersecretion of mucus, cell hyperplasia, and even fusion of the filaments of gill lamellae, reducing the host's respiratory capacity (THATCHER; BRITES-NETO, 1994; PAVANELLI et al., 2008).

In severe infestations, ciliate protozoans can damage fish health and consequently cause economic losses in fish farming systems. Trichodina spp. and I. multifiliis occur in the gills and on the body surface of fish and may cause mucus hypersecretion and lesions in the integument and gills (PAVANELLI et al., 2008). Several studies have reported the occurrence of these parasites in $O$. niloticus and their associations with limnological data or seasonality (TAVARES-DIAS et al., 2001a, b; RANZANI-

Table 1. Dominance frequency and mean relative dominance of the ectoparasites found in Nile tilapia (Oreochromis niloticus) reared in fish cages in the Grande River Basin, Água Vermelha Reservoir, Southeastern Brazil, March 2010-March 2011.

\begin{tabular}{lcc}
\hline \multicolumn{1}{c}{ Ectoparasites } & $\begin{array}{c}\text { Dominance } \\
\text { frequency }\end{array}$ & $\begin{array}{c}\text { Mean relative } \\
\text { dominance* }\end{array}$ \\
\hline Trichodina spp. & 45 & $0.6 \pm 0.3$ \\
Ichthyophthirius multifiliis & 0 & $0.01 \pm 0.02$ \\
Cichlidogyrus halli & 14 & $0.2 \pm 0.3$ \\
Cichlidogyrus thurstonae & 4 & $0.1 \pm 0.2$ \\
Cichlidogyrus sp. 1 & 0 & $0.001 \pm 0.1$ \\
Scutogyrus longicornis & 0 & $0.03 \pm 0.1$ \\
Gyrodactylus sp. & 0 & $0.04 \pm 0.1$ \\
\hline
\end{tabular}

*Values presented as mean \pm standard error (range).
PAIVA et al., 2005; LEMOS et al., 2006; LIZAMA et al., 2007; BRACCINI et al., 2008; BUCUR et al., 2011; JERÔNIMO et al., 2011). However, there has been a lack of studies on the association between disease occurrence and parasitism rates in $O$. niloticus during the different growth phases.

Thus, for this study, we aimed to perform a parasitological analysis of cage-cultured $O$. niloticus of the Água Vermelha Reservoir, Southeastern Brazil, and to verify any associations with limnological data, seasonality, and fish growth phase.

\section{Materials and Methods}

\section{Characterization of fish farming}

This study was carried out in an $O$. niloticus cage farm located in the Grande River Basin, Água Vermelha Reservoir (Figure 1), municipality of Mira Estrela, Sáo Paulo State, Brazil (19 ${ }^{\circ} 55^{\prime}$ 47.52" S, $50^{\circ} 08^{\prime} 36.56$ ” W). The fish cages, sized $6 \mathrm{~m}^{3}$, were positioned in parallel lines. Fish were stocked at a density of $80 \mathrm{~kg} / \mathrm{m}^{3}$ and were fed twice daily (at 8:00 AM and 4:00 PM), in accordance with the recommendations of the feed manufacturer, considering fish size and water temperature. The fish were harvested when their average weight reached $800 \mathrm{~g}$, and they were sold to cold storage plants to be processed and filleted or to fee-fishing farms. The fish production cycle took approximately 4 months.

\section{Parasitological procedures}

From March 2010 to March 2011, nine specimens of $O$. niloticus across the three growth phases (three each from the initial, intermediate, and final phases) were collected bimonthly, totaling 63 individuals. Fish growth phase was determined according to fish weight (initial, intermediate, and final phases: $\leq 150 \mathrm{~g}$, 151-400 g, and 401-800 g, respectively). The fish were caught with nets and transported to the laboratory, where they were measured (cm) and weighed (g) (Table 1). Oreochromis niloticus specimens were necropsied according to Eiras et al. (2006). Qualitative and quantitative analyses of protozoan parasites were performed on mucus scrapings from the entire body surface on microscope slides after fixation in 70\% alcohol. Subsequently, all this content was analyzed with an optical microscope by compressing them between a microscope slide and a cover slip; excess liquid was removed using filter paper (adapted from EIRAS et al., 2006).

All organs were analyzed with a stereo microscope. The gills were collected and fixed in $70 \%$ alcohol for later identification and the counting of monogenoids. To study sclerotized structures (hooks, anchors and bars of haptor, and copulatory complex), the monogenoids were clarified with Hoyer's medium or Grey and Wess (EIRAS et al., 2006). The following references were used for parasite identification and diagnosis: Douëllou (1993) and Pariselle and Euzet (2009) for monogenoids and Van As and Basson (1989), Martins and Ghiraldelli (2008), and Pavanelli et al. (2008) for protozoans. 


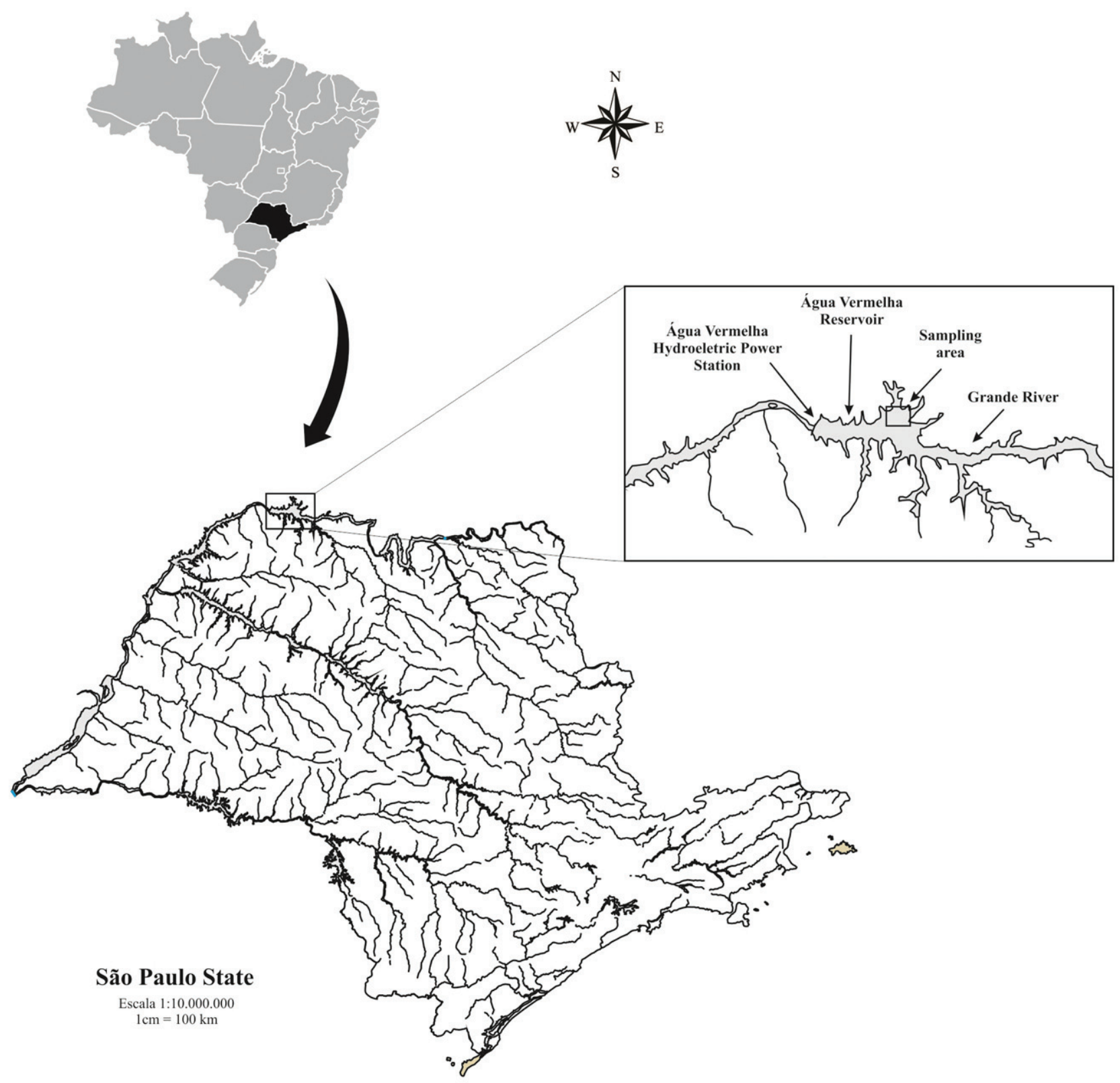

Figure 1. Map of Brazil highlighting São Paulo State and the sampling area of the Água Vermelha reservoir (195 5 '47.52” S, 5008’36.56” W).

For species identification, parasites were analyzed using a computerized image analysis system with differential interference contrast (DIC) - LAS V3 (Leica Application Suite). Voucher specimens were deposited at the Coleção Helmintológica of the Departamento de Parasitologia, Instituto de Biociências, Universidade Estadual Paulista - UNESP, municipality of Botucatu, São Paulo State, Brazil (CHIBB: 055L-067L).

\section{Water quality}

Water samples were obtained bimonthly from the investigated fish farm. The water's physical and chemical parameters, such as dissolved oxygen and temperature, were evaluated in situ using a YSY - Mod. 50 multisensor, and its transparency was measured with a Secchi Disk. Nitrite concentration $(\mathrm{mg} / \mathrm{L})$, total ammonia nitrogen concentration $(\mathrm{mg} / \mathrm{L})$, and $\mathrm{pH}$ were measured using a commercial kit (AlfaKit; Alfa Techno Chemistry Company, Florianópolis, SC, Brazil).

\section{Data analysis}

Parasite prevalence, mean intensity of infection, and mean abundance data were obtained according to Bush et al. (1997), and the frequency of dominance and mean relative dominance were determined according to Rohde et al. (1995).

Comparisons of the prevalence of each species of parasite in relation to seasonality were performed using $Z$-tests, and comparisons in relation to fish growth phase were performed 
using chi-square $\left(\chi^{2}\right)$ tests of independence and a posteriori tests of adjusted residuals.

The variation of intensity of infection and abundance in relation to seasonality were compared by Student's $t$ - or Mann-Whitney $U$-tests, according to data distribution. Variation in the intensity of infection and abundance of parasites among the fish growth phases were compared by one-way analyses of variance (ANOVAs) or Kruskal-Wallis $(H)$ tests, according to data distribution.

The condition factor $(K)$ was calculated using the curve of the relationship between the total weight (Wt) and standard length $(\mathrm{L})$ of $O$. niloticus specimens; a scatter plot of the variables (Wt and $\mathrm{L}_{\mathrm{s}}$ ) was used (LE CREN, 1951). The ratio Wt / $\mathrm{L}_{\mathrm{s}}$ was adjusted by an exponential equation of the type Wt $=a \times \mathrm{L}_{\mathrm{s}}^{b}$, where the $a$ constant (linear coefficient) indicates fish health and the $b$ parameter (angular coefficient) expresses the fish species' type of growth (SANTOS, 1978; BENEDITO-CECÍLIO; AGOSTINHO, 1997; ORSI et al., 2004). The individual condition factor $\left(K=\mathrm{Wt} / \mathrm{Lt}^{b}\right)$ for each fish specimen was calculated using the angular coefficient. Spearman's rank correlation $\left(r_{s}\right)$ analysis was used to study any possible correlation between the condition factor $(K)$ and abundance according to seasonality and fish growth phase.

Tricodinids were quantified only at the genus level, and because of this they were not quantified separately for statistical analysis.

The calculations of the mean intensity of infection and mean abundance were not performed for Epistylis sp., because it is a colonial protozoan.

Statistical tests were performed using SigmaStat 3.1 (Systat Software Inc., California, USA) and XLStat 7.5.2 (Addinsoft, New York, USA), adopting a significance level of 5\%.

\section{Results}

\section{Ectoparasites}

All fish specimens were infested with at least one species of ectoparasite (prevalence $=100 \%$ ), and the presence of the following taxa was observed: Trichodina compacta Van As \& Basson, 1989, Trichodina magna Van As \& Basson, 1989, I. multifiliis and Epistylis sp. Ehrenberg, 1830 parasitizing the body surface and gills; Piscinoodinium pillulare (Schäperclaus, 1954) Lom, 1981, Cichlidogyrus halli (Price \& Kirk, 1967), Cichlidogyrus thurstonae Ergens, 1981, Cichlidogyrus sp.1 Paperna, 1960 and Scutogyrus longicornis (Paperna \& Thurston, 1969) parasitizing only the gills; and Gyrodactylus sp. Nordmann, 1832, parasitizing only the body surface. Trichodina spp. showed a higher frequency of dominance and mean relative dominance among the parasites found in this study (Table 1).

\section{Fish growth phase}

Fish specimens from the intermediate and final phases presented higher mean intensity of infection and mean abundance than those from the initial phase $(H=10.7, p=0.005$; Table 2$)$. Trichodina spp. had the highest mean abundance values of any parasites in all fish growth phases $(p<0.05)$. In relation to mean intensity of infection, this protozoan also showed the highest parasitism rates $(p<0.05)$, with the exception of $I$. multifiliis in the intermediate phase.

Analysing in which fish growth phase determined ectoparasite species presented the higher parasitism rates, Nile tilapia in the intermediate and final phases presented the highest intensity of infection and abundance of Trichodina spp. $(H=6.9, p=0.03$ and $H=11.5, p=0.003$, respectively) and $S$. longicornis $(H=12.9$, $p=0.002$ and $H=18.8, p<0.001$, respectively). Fish specimens from the final phase had the highest prevalence of Cichlidogyrus sp. 1 $(p<0.05)$ and I. multifiliis $(p<0.05)$, and the highest abundance of $C$. halli $(H=7.1, p=0.03$; Table 3$)$.

No correlation was observed in the fish growth phases in relation to $K$ or parasite abundance $(p>0.05)$.

\section{Water quality and seasonality}

The water parameters of the studied fish farm are presented in Table 4. In the dry season, Trichodina spp. $(U=1010.5, p=0.043)$ was the most abundant parasite, and Epistylis sp. $(Z=2.739$, $p=0.006$ ) was the most prevalent. In the rainy season, there was a higher prevalence $(Z=2.239, p=0.025)$ of $C$. halli (Table 5).

No correlation was observed in the dry or rainy seasons in relation to $K$ or parasite abundance $(p>0.05)$.

Table 2. Prevalence (P), mean intensity of infection (MII), and mean abundance (MA) of the ectoparasites and biometric data observed in each fish growth phase of Nile tilapia (Oreochromis niloticus) reared in fish cages in the Grande River Basin, Água Vermelha Reservoir, Southeastern Brazil, March 2010-March 2011.

\begin{tabular}{lccccc}
\hline \multicolumn{1}{c}{ Fish growth phase } & Weight $\mathbf{( g )}$ & Standard length $\mathbf{( c m})$ & $\mathbf{P}(\mathbf{\%})$ & MII $^{\mathbf{*}}$ & MA $^{\mathbf{*}}$ \\
\hline Initial & $56.4 \pm 13.7$ & $10.06 \pm 0.9$ & $100^{\mathrm{a}}$ & $25 \pm 5.9$ & $25 \pm 5.9$ \\
& $(1.4-214.3)$ & $(4.2-17.2)$ & & $(2-108)^{\mathrm{a}}$ & $(2-108)^{\mathrm{a}}$ \\
Intermediate & $228.4 \pm 27.4$ & $18 \pm 0.8$ & $100^{\mathrm{a}}$ & $181 \pm 94.3$ & $181 \pm 94.3$ \\
& $(59.8-444.6)$ & $(13-23.5)$ & & $(10-2030)^{\mathrm{b}}$ & $(10-2030)^{\mathrm{b}}$ \\
Final & $590.6 \pm 59.6$ & $24.2 \pm 0.8$ & $100^{\mathrm{a}}$ & $581.2 \pm 387.6$ & $581.2 \pm 387.6$ \\
& $(205.4-1481.1)$ & $(17-32)$ & & $(4-8199)^{\mathrm{b}}$ & $(4-8199)^{\mathrm{b}}$ \\
\hline
\end{tabular}

*Values presented as mean \pm standard error (range). g: gram; $\mathrm{cm}$ : centimeter. Prevalence, mean intensity of infection and mean abundance followed by the same letter in the column: no significant difference $(p>0.05)$. Epistylis sp. was not included in the calculations of mean intensity of infection and mean abundance because it is a colonial protozoan. 
Table 3. Prevalence, mean intensity of infection, and mean abundance of the ectoparasites found in each fish growth phase (IN: initial $-n=21$, IT: intermediate $-n=21$, and FN: final $-n=21$ ) of Nile tilapia (Oreochromis niloticus) reared in fish cages from the Grande River Basin, Água Vermelha Reservoir, Southeastern Brazil, March 2010-March 2011.

\begin{tabular}{|c|c|c|c|c|c|c|c|c|c|}
\hline \multirow{2}{*}{ Ectoparasites } & \multicolumn{3}{|c|}{ Prevalence (\%) } & \multicolumn{3}{|c|}{ Mean intensity of infection* } & \multicolumn{3}{|c|}{ Mean abundance* } \\
\hline & IN & IT & FN & IN & IT & FN & IN & IT & FN \\
\hline Trichodina spp. & $76.2^{\mathrm{a}}$ & $100^{\mathrm{a}}$ & $90.5^{a}$ & $\begin{array}{c}23.9 \pm 7.1 \\
(2-96)^{\mathrm{a}}\end{array}$ & $\begin{array}{l}159.3 \pm 83 \\
(2-1778)^{\mathrm{b}}\end{array}$ & $\begin{array}{c}603 \pm 405.3 \\
(2-7768)^{b}\end{array}$ & $\begin{array}{c}18.2 \pm 5.8 \\
(0-96)^{\mathrm{a}}\end{array}$ & $\begin{array}{l}159.3 \pm 83 \\
(2-1778)^{\mathrm{b}}\end{array}$ & $\begin{array}{c}545.5 \pm 367.9 \\
(0-7768)^{\mathrm{b}}\end{array}$ \\
\hline $\begin{array}{l}\text { Ichthyophthirius } \\
\text { multifiliis }\end{array}$ & $0^{\mathrm{a}}$ & $9.5^{\mathrm{a}}$ & $38.1^{b}$ & $0^{\mathrm{a}}$ & $\begin{array}{l}100 \pm 98 \\
(2-198)^{\mathrm{a}}\end{array}$ & $\begin{array}{c}51.1 \pm 1 \\
(2-10)^{\mathrm{a}}\end{array}$ & $0^{\mathrm{a}}$ & $\begin{array}{l}9.5 \pm 9.4 \\
(0-198)^{\mathrm{a}}\end{array}$ & $\begin{array}{c}1.9 \pm 0.7 \\
(0-10)^{\mathrm{a}}\end{array}$ \\
\hline Epistylis sp. ${ }^{\dagger}$ & $19.1^{\mathrm{a}}$ & $52.4^{\mathrm{a}}$ & $57.14^{\mathrm{a}}$ & - & - & - & - & - & - \\
\hline $\begin{array}{l}\text { Piscinoodinium } \\
\text { pillulare }\end{array}$ & $4.8^{\mathrm{a}}$ & $0^{\mathrm{a}}$ & $0^{\mathrm{a}}$ & $1^{\text {a }}$ & $0^{\mathrm{a}}$ & $0^{\mathrm{a}}$ & $\begin{array}{l}0.1 \pm 0.1 \\
\quad(0-1)^{\mathrm{a}}\end{array}$ & $0^{\mathrm{a}}$ & $0^{\mathrm{a}}$ \\
\hline Cichlidogyrus halli & $61.9^{\mathrm{a}}$ & $100^{\mathrm{a}}$ & $90.5^{\mathrm{a}}$ & $\begin{array}{c}5.3 \pm 1.8 \\
(0.7-23.5)^{\mathrm{a}}\end{array}$ & $\begin{array}{c}4.5 \pm 0.7 \\
(0.9-13.5)^{\mathrm{a}}\end{array}$ & $\begin{array}{l}7.2 \pm 2.6 \\
(0.6-45.5)^{\mathrm{a}}\end{array}$ & $\begin{array}{l}3.3 \pm 1.2 \\
(0-23.5)^{\mathrm{a}}\end{array}$ & $\begin{array}{c}4.5 \pm 0.7 \\
(0.9-13.5)^{\mathrm{a}}\end{array}$ & $\begin{array}{c}8 \pm 2.4 \\
(0-45.5)^{\mathrm{b}}\end{array}$ \\
\hline $\begin{array}{l}\text { Cichlidogyrus } \\
\text { thurstonae }\end{array}$ & $57.1^{\mathrm{a}}$ & $95.2^{\mathrm{a}}$ & $85.7^{\mathrm{a}}$ & $\begin{array}{l}2.4 \pm 0.9 \\
(0.3-9.7)^{\mathrm{a}}\end{array}$ & $\begin{array}{c}4.7 \pm 1.6 \\
(0.3-25.5)^{\mathrm{a}}\end{array}$ & $\begin{array}{c}4.2 \pm 0.7 \\
(0.8-12.2)^{\mathrm{a}}\end{array}$ & $\begin{array}{c}1.4 \pm 2.5 \\
(0-9.7)^{\mathrm{a}}\end{array}$ & $\begin{array}{l}4.5 \pm 1.4 \\
(0-25.5)^{\mathrm{a}}\end{array}$ & $\begin{array}{c}4 \pm 0.7 \\
(0-12.2)^{\mathrm{a}}\end{array}$ \\
\hline Cichlidogyrus sp. 1 & $0^{\mathrm{a}}$ & $0^{\mathrm{a}}$ & $61.9^{\mathrm{b}}$ & $0^{\mathrm{a}}$ & $0^{\mathrm{a}}$ & $\begin{array}{l}0.2 \pm 0.1 \\
(0.01-1)^{\mathrm{a}}\end{array}$ & $0^{\mathrm{a}}$ & $0^{\mathrm{a}}$ & $\begin{array}{l}0.1 \pm 0.1 \\
\quad(0-1)^{\mathrm{a}}\end{array}$ \\
\hline $\begin{array}{l}\text { Scutogyrus } \\
\text { longicornis }\end{array}$ & $42.9^{\mathrm{a}}$ & $85.7^{\mathrm{a}}$ & $76.2^{a}$ & $\begin{array}{c}0.3 \pm 0.1 \\
(0.1-1)^{\mathrm{a}}\end{array}$ & $\begin{array}{c}1.6 \pm 0.4 \\
(0.3-6)^{b}\end{array}$ & $\begin{array}{l}1.7 \pm 0.5 \\
(0.1-8.2)^{\mathrm{b}}\end{array}$ & $\begin{array}{c}0.1 \pm 0.1 \\
(0-1)^{\mathrm{a}}\end{array}$ & $\begin{array}{l}1.4 \pm 0.3 \\
(0-6)^{\mathrm{b}}\end{array}$ & $\begin{array}{c}1.3 \pm 0.4 \\
(0-8.2)^{\mathrm{b}}\end{array}$ \\
\hline Gyrodactylus sp. & $33.3^{\mathrm{a}}$ & $33.3^{\mathrm{a}}$ & $47.6^{\mathrm{a}}$ & $\begin{array}{c}5.7 \pm 1.5 \\
(2-12)^{\mathrm{a}}\end{array}$ & $\begin{array}{c}7 \pm 3 \\
(1-24)^{\mathrm{a}}\end{array}$ & $\begin{array}{c}44.2 \pm 38.3 \\
(1-388)^{\mathrm{a}}\end{array}$ & $\begin{array}{c}1.9 \pm 0.8 \\
(0-12)^{\mathrm{a}}\end{array}$ & $\begin{array}{c}2.3 \pm 1.2 \\
(0-24)^{\mathrm{a}}\end{array}$ & $\begin{array}{c}21.1 \pm 18.4 \\
(0-388)^{\mathrm{a}}\end{array}$ \\
\hline
\end{tabular}

*Values presented as mean \pm standard error (range). †The calculations of mean intensity of infection and mean abundance were not performed as this is a colonial protozoan. Prevalence, mean intensity of infection and mean abundance followed by the same letter in the row: no significant difference $(p>0.05)$.

Table 4. Water quality measured in the Grande River Basin, Água Vermelha Reservoir, Southeastern Brazil close to the fish farming cage culture of Oreochromis niloticus, March 2010-March 2011.

\begin{tabular}{|c|c|c|c|c|c|c|c|}
\hline \multirow{2}{*}{ Parameters } & \multicolumn{7}{|c|}{ Sampling months } \\
\hline & Mar/10* & May/10 ${ }^{\dagger}$ & $\mathrm{Jul} / 10^{\dagger}$ & Sept $/ 10^{\dagger}$ & Nov/10* & $\operatorname{Jan} / 11^{*}$ & $\operatorname{Mar} / 11^{*}$ \\
\hline Dissolved oxygen $\left(\mathrm{mg} \cdot \mathrm{L}^{-1}\right)$ & 6.6 & 6.7 & 6.3 & 7.6 & 3.9 & 6.2 & 5.2 \\
\hline Transparency $(\mathrm{m})$ & 2 & $>2$ & $>1.5$ & 1.5 & 0.98 & $>1.5$ & $>1.5$ \\
\hline $\mathrm{pH}$ & 7 & 7 & 7 & 6.8 & 6.5 & 7.5 & 7 \\
\hline Temperature $\left({ }^{\circ} \mathrm{C}\right)$ & 29.3 & 24.5 & 22.9 & 23.6 & 28.6 & 30.8 & 28.6 \\
\hline Ammonia (mg. $\left.\mathrm{L}^{-1}\right)$ & 0.1 & 0 & 0 & 0.1 & 0.1 & 0.1 & 0.1 \\
\hline Toxic ammonia (mg.L $\left.\mathrm{L}^{-1}\right)$ & $9 \times 10^{-4}$ & 0 & 0 & $6 \times 10^{-4}$ & $2.3 \times 10^{-4}$ & $2.3 \times 10^{-4}$ & $9 \times 10^{-4}$ \\
\hline Nitrite $\left(\mathrm{mg} \cdot \mathrm{L}^{-1}\right)$ & 0.1 & 0.03 & 0 & 0 & 0.03 & 0.1 & 0.03 \\
\hline Rainfall $(\mathrm{mm})^{\ddagger}$ & 147.3 & 58.9 & 14.1 & 64.5 & 124 & 271.6 & 147.3 \\
\hline
\end{tabular}

${ }^{*}$ Months belonging to the rainy season (Mar: March, Nov: November, Jan: January); ${ }^{\dagger}$ Months belonging to the dry season (May, Jul: July, Sept: September); ${ }^{\ddagger}$ Rainfall data were obtained by consulting the database CIIAGRO - Centro Integrado de Informaçóes Agrometeorológicas of the São Paulo State, Brazil.

\section{Discussion}

The ectoparasites found in this study are commonly observed in $O$. niloticus and have been described in several previous reports under various culture systems (VARGAS et al., 2000; MARTINS et al., 2001; TAVARES-DIAS et al., 2001a, b; RANZANI-PAIVA et al., 2005; GHIRALDELLI et al., 2006; LEMOS et al., 2006; BRACCINI et al., 2008; BUCUR et al., 2011; JERÔNIMO et al., 2011).

The majority of the values observed in the water analysis were appropriate for farming of $O$. niloticus, with the exception of temperature, which in dry season months was lower $\left(<26^{\circ} \mathrm{C}\right)$ than that recommended for this fish species (KUBITZA, 2000;
ZANIBONI-FILHO, 2004). In the dry season, there was a higher abundance of Trichodina spp. and prevalence of Epistylis sp.

According to Pavanelli et al. (2008), the susceptibility of fish to parasites and diseases depends on several factors related to stress caused by nutritional status, handling or transport and, particularly, water quality and organic load of the production units. Low temperature can reduce appetite and growth and suppress the immune system, predisposing the fish to attack by pathogens (KUBITZA, 2000).

During the rainy season, only the prevalence of $C$. halli was higher than that observed during the dry season. However, the mean intensity of infection and mean abundance of $C$. halli and the other monogenoids observed in this study were low in both of the studied periods. A similar result was observed by 
Table 5. Prevalence (P), mean intensity of infection (MII), and mean abundance (MA) of the ectoparasites found in Nile tilapia (Oreochromis niloticus) reared in fish cages in the Grande River Basin, Água Vermelha Reservoir, Southeastern Brazil, according to seasonality, March 2010-March 2011.

\begin{tabular}{|c|c|c|c|c|c|c|}
\hline \multirow{2}{*}{ Ectoparasites } & \multicolumn{2}{|c|}{$\mathbf{P}(\%)$} & \multicolumn{2}{|c|}{ MII* } & \multicolumn{2}{|c|}{ MA* } \\
\hline & DS $^{r}$ & $\mathbf{R S}^{\boldsymbol{\lambda}}$ & DS $^{x}$ & $\mathbf{R S}^{\boldsymbol{\lambda}}$ & DS $^{r}$ & $\mathbf{R S}^{\tilde{\lambda}}$ \\
\hline Trichodina spp. & $96.3^{\mathrm{a}}$ & $83.3^{\mathrm{a}}$ & $472.8 \pm 302.5(4-7768)^{\mathrm{a}}$ & $96.4 \pm 33.8(2-926)^{a}$ & $455.3 \pm 291.6(4-7768)^{\mathrm{a}}$ & $80.3 \pm 28.8(0-926)^{b}$ \\
\hline Ichthyophthirius multifiliis & $28.6^{\mathrm{a}}$ & $11.1^{\mathrm{a}}$ & $37.7 \pm 32.1(2-198)^{\mathrm{a}}$ & $3.8 \pm 1.2(2-7)^{\mathrm{a}}$ & $8.4 \pm 7.3(0-198)^{\mathrm{a}}$ & $0.4 \pm 0.2(0-7)^{\mathrm{a}}$ \\
\hline Epistylis sp. ${ }^{\dagger}$ & $71.4^{\mathrm{a}}$ & $33.3^{\mathrm{b}}$ & - & - & - & - \\
\hline Piscinoodinium pillulare & $11.1^{\mathrm{a}}$ & $0^{\mathrm{a}}$ & $1^{\text {a }}$ & $0^{\mathrm{a}}$ & $0.1 \pm 0.1(0-1)^{\mathrm{a}}$ & $0^{\mathrm{a}}$ \\
\hline Cichlidogyrus halli & $70.4^{a}$ & $94.4^{\mathrm{b}}$ & $5.1 \pm 1.2(0.7-18.8)^{\mathrm{a}}$ & $6.4 \pm 1.6(0.6-45.5)^{\mathrm{a}}$ & $3.6 \pm 0.9(0-18.8)^{\mathrm{a}}$ & $6.1 \pm 1.5(0-45.5)^{\mathrm{a}}$ \\
\hline Cichlidogyrus thurstonae & $90.5^{a}$ & $86.1^{\mathrm{a}}$ & $3.7 \pm 0.8(0.3-12.2)^{\mathrm{a}}$ & $4.1 \pm 1(0.3-24.5)^{a}$ & $2.6 \pm 0.7(0-12.2)^{\mathrm{a}}$ & $3.5 \pm 0.9(0-24.5)^{\mathrm{a}}$ \\
\hline Cichlidogyrus sp. 1 & $18.5^{\mathrm{a}}$ & $22.2^{\mathrm{a}}$ & $0.4 \pm 0.2(0.03-1)^{\mathrm{a}}$ & $0.2 \pm 0.1(0.01-0.9)^{\mathrm{a}}$ & $0.1 \pm 0.04(0-1)^{\mathrm{a}}$ & $0.04 \pm 0.03(0-0.9)^{\mathrm{a}}$ \\
\hline Scutogyrus longicornis & $59.3^{\mathrm{a}}$ & $75^{a}$ & $1.7 \pm 0.4(0.02-6)^{a}$ & $1.2 \pm 1.6(0.05-8.2)^{\mathrm{a}}$ & $1 \pm 0.3(0-6)^{\mathrm{a}}$ & $0.9 \pm 0.3(0-8.2)^{\mathrm{a}}$ \\
\hline Gyrodactylus sp. & $48.2^{\mathrm{a}}$ & $30.6^{\mathrm{a}}$ & $36.3 \pm 29.4(2-388)^{\mathrm{a}}$ & $5.4 \pm 1.6(1-18)^{\mathrm{a}}$ & $17.5 \pm 14.3(0-388)^{\mathrm{a}}$ & $1.6 \pm 0.6(0-18)^{\mathrm{a}}$ \\
\hline Total & $100^{a}$ & $100^{\mathrm{a}}$ & $506.1 \pm 322.4(0-8166)^{a}$ & $94.2 \pm 30.1(2-943)^{a}$ & $506.1 \pm 322.4(0-8166)^{a}$ & $94.2 \pm 30.1(2-943)^{\mathrm{a}}$ \\
\hline
\end{tabular}

${ }^{*}$ Values presented as mean \pm standard error (range). ${ }^{r} \mathrm{DS}$ : dry season (April to September) - $n=36$; ${ }^{\star} \mathrm{RS}$ : Rainy season (October to March) - $n=27 .{ }^{\dagger}$ The calculations of mean intensity of infection and mean abundance were not performed as this is a colonial protozoan. Prevalence, mean intensity of infection and mean abundance followed by the same letter in the row: no significant difference $(p>0.05)$.

Ranzani-Paiva et al. (2005) when studying O. niloticus from Guarapiranga Reservoir, São Paulo State, Brazil. In that study, Ranzani-Paiva et al. (2005) observed a low mean intensity of infection of Cichlidogyrus sp., with a higher prevalence in the Brazilian rainy season (i.e., October, November, and December). Likewise, Zica (2008) studied O. niloticus reared in fish cages in the Chavantes Reservoir, São Paulo State, Brazil, observed a high prevalence of monogenoids, especially during the rainy season; however, the intensity of infection and abundance were low in both of the evaluated periods (rainy and dry seasons).

According to Eiras (1994), the majority of monogenoid species had well-defined annual patterns of infection, with an increased number of parasites at higher temperatures (i.e., the rainy season) and a decrease at lower temperatures (i.e., the dry season).

The seasonality results observed in this study corroborate the findings of Jerônimo et al. (2011), who observed higher rates of infestation by protozoans in $O$. niloticus reared in three regions of Santa Catarina State, Brazil during lower-temperature months (i.e., the autumn and winter) and an increase in monogenoid parasitism rates in higher-temperature months (i.e., the spring and summer).

Trichodinid parasites have great significance in the commercial production of tilapia and occur in a wide quantity of fishfarming systems (GHIRALDELLI et al., 2006). In the present study, Trichodina spp. presented with the highest frequency of dominance and mean relative dominance, and the highest parasitism rates during all fish growth phases and periods of the year. Ghiraldelli et al. (2006) studied ectoparasites in O. niloticus reared in three regions of Santa Catarina State, Brazil and found similar results: trichodinids were the most numerous parasites and served as the dominant parasite group. Similarly, RanzaniPaiva et al. (2005) observed that Trichodina spp. had the highest infection rates in $O$. niloticus from the Guarapiranga Reservoir, São Paulo State, Brazil.

Fish in the intermediate and final phases had higher parasitism rates than those in the initial phase. As reported by Zuben (1997), host body size is the factor most strongly correlated with the number of parasite species present. Larger hosts may offer more space to parasites and harbor more species. Consequently, a greater variety of niches is available for occupation, allowing the simultaneous occurrence of more parasite species (POULIN, 1995). In addition, major hosts release large amounts of nitrogen compounds, which accumulate in the fish cages and may increase the parasitism rates of some parasite species, such as Trichodina spp. Studies comparing parasitism rates across growth phases in $O$. niloticus are scarce, and they usually investigate the occurrence of parasitism in only one fish growth phase; an especially common choice is the fingerling phase.

The only report in the literature that compares fish growth phases was performed by Vargas et al. (2000), who studied $O$. niloticus reared in ponds from the municipality of Umuarama, Paraná State, Brazil. Those authors compared parasitism rates in the fingerling and reproductive phases. The total prevalence of ectoparasites in fingerlings was $87 \%$, with a higher occurrence of Trichodina sp. than monogenoids (36\% and $15 \%$, respectively). A total prevalence of $31 \%$ was observed in the reproductive phase, with a higher incidence of monogenoids than Trichodina sp. (14\% and $12 \%$, respectively).

In the present study, no correlations of $K$ or parasite abundance were observed with respect to either fish growth phase or seasonality. This result suggests that, although the fish were more parasitized in the intermediate and final phases and the dry season, these parasitism rates were not enough to affect the physiological state, health, or welfare of the fish. Furthermore, the adequate aspects of handling used in the fish farm studied, such as the reduced fish stocking densities $\left(80 \mathrm{~kg} / \mathrm{m}^{3}\right)$ and the adequate water quality of the Água Vermelha reservoir, could have contributed to the observed result.

This study reports on the main parasites that affect the cultivation of $O$. niloticus, and the data obtained indicate that seasonality and fish growth phase can influence the occurrence of these organisms. Moreover, the presented data may be of great importance to fish farmers to help them to understand the parasite dynamics of the studied fish species in cage farming systems. 


\section{Acknowledgements}

The authors thank Fundação de Amparo à Pesquisa do Estado de Sáo Paulo - FAPESP (Process 2010/01424-0), Conselho Nacional de Desenvolvimento Científico e Tecnológico - CNPq (Process 577649/2008-6) and Coordenação de Aperfeiçoamento de Pessoal de Nível Superior - CAPES for financial support. We are grateful to Luis Borges for donating the fish analyzed in this study; Daiane M. Romera, Pedro G. P. Candeira, and Fernando $S$. Fonseca for logistical support during the collections; and Dr. Maurício L. Martins and Dr. Eduardo M. Onaka for their critical reviews of this article.

\section{References}

Benedito-Cecílio E, Agostinho AA. Estrutura de populaçôes de peixes do reservatório de Segredo. In: Agostinho AA, Gomes LC. Reservatório de Segredo: bases ecológicas para o manejo. Maringá: Eduem; 1997. p. 113-139.

Braccini GL, Vargas L, Ribeiro RP, Filho LA, Digmayer M. Ectoparasitos de tilápia do nilo (Oreochromis niloticus) cultivados em tanquesrede nos rios do Corvo e Guairacá, Paraná, Brasil. Rev Bras Parasitol Vet 2008; 17(S1): 24-9. PMid:20059810.

Bucur C, Costache M, Popa V, Oprea D. Contributions to the knowledge of parasite fauna on Oreochromis niloticus species reared in flow-through installations and earthen ponds. Bulletin UASVM Animal Science and Biotechnologies 2011; 68(1-2): 98-103.

Bush AO, Lafferty KD, Lotz JM, Shostak AW. Parasitology meets ecology on its own terms: Margolis et al. revisited. J Parasitol 1997; 83(4): 575-83. PMid:9267395. http://dx.doi.org/10.2307/3284227

Cavichiolo F, Vargas L, Ribeiro RP, Moreira HLM, Leonardo JM. Níveis de suplementação de vitamina $\mathrm{C}$ na ração sobre a ocorrência de ectoparasitas, sobrevivência e biomassa em alevinos de tilápia do Nilo (Oreochromis niloticus L.). Acta Sci 2002; 24(4): 957-64.

Douëllou L. Monogeneans of the genus Cichlidogyrus Paperna, 1960 (Dactylogyridae: Ancyrocephalinae) from cichlid fishes of the Lake Kariba (Zimbabwe) with descriptions of five new species. Syst Parasitol 1993; 25(3): 159-86. http://dx.doi.org/10.1007/BF00007007

Eiras JC, Takemoto RM, Pavanelli GC. Métodos de estudo e técnicas laboratoriais em parasitologia de peixes. 2. ed. Maringá: Eduem; 2006. 199 p.

Eiras JC. Elementos de ictioparasitologia. Porto: Fundação Engenheiro António de Almeida; 1994. 339 p.

Ghiraldelli L, Martins ML, Jerônimo GT, Yamashita MM, Adamante WB. Ectoparasites communities from Oreochromis niloticus cultivated in the State of Santa Catarina, Brazil. J Fish Aquat Sci 2006; 1(2): 181-90. http://dx.doi.org/10.3923/jfas.2006.181.190

Jerônimo GT, Speck GM, Cechinel MM, Gonçalves ELT, Martins ML. Seasonal variation on the ectoparasitic communities of Nile tilapia cultured in three regions in southern Brazil. Braz J Biol2011;71(2): 365-73. PMid:21755153. http://dx.doi.org/10.1590/ S1519-69842011000300005

Kubitza F. Tilápia: tecnologia e planejamento na produção comercial. Jundiaí: F. Kubitza; 2000. 289 p.

Le Cren ED. The length-weight relationship and seasonal cycle in gonad weight and condition in the perch (Perca fluviatilis). J Anim Ecol 1951; 20(2): 201-19. http://dx.doi.org/10.2307/1540
Lemos JB, Rodrigues MEB, Lopes JP. Diagnóstico de ectoparasitas e bactérias em tilápias (Oreochromis niloticus) cultivadas na região de Paulo Afonso, Bahia. Rev Bras Eng Pesca 2006; 1(1): 75-90.

Lizama MAP, Takemoto RM, Ranzani-Paiva MJT, Ayroza LMS, Pavanelli GC. Relação parasito-hospedeiro em peixes de pisciculturas da região de Assis, Estado de São Paulo, Brasil. 1. Oreochromis niloticus (Linnaeus, 1757). Acta Sci Biol Sci 2007; 29(2): 223-31. http://dx.doi. org/10.4025/actascibiolsci.v29i2.594

Martins ML, Ghiraldelli L. Trichodina magna Van As and Basson, 1989 (Ciliophora: Peritrichia) from cultured Nile tilapia in the state of Santa Catarina, Brazil. Braz J Biol 2008; 68(1): 169-72. http://dx.doi. org/10.1590/S1519-69842008000100024

Martins ML, Moraes JRE, Andrade PM, Schalch SHC, Moraes FR. Piscinoodinium pillulare (Schäperclaus, 1954) Lom, 1981 (Dinoflagellida) infection in cultivated freshwater fish from the Northeast region of São Paulo State, Brazil: parasitological and pathological aspects. Braz J Biol2001; 61(4): 639-44. PMid:12071320. http://dx.doi.org/10.1590/ S1519-69842001000400013

Martins ML, Onaka EM, Moraes FR, Bozzo FR, Paiva AMFC, Gonçalves A. Recent studies on parasitic infections of freshwater cultivated fish in the state of São Paulo, Brazil. Acta Sci 2002; 24(4): 981-5.

Martins ML, Shoemaker CA, Xu D, Klesius PH. Effect of parasitism on vaccine efficacy against Streptococcus iniae in Nile tilapia. Aquaculture 2011; 314(1-4): 18-23. http://dx.doi.org/10.1016/j. aquaculture.2011.01.022

Ono EA, Kubitza F. Cultivo de peixes em tanques-rede. 2. ed. Jundiaí: F. Kubitza; 1999. 68 p.

Orsi ML, Carvalho ED, Foresti F. Biologia populacional de Astyanax altiparanae Garutti \& Britski (Teleostei, Characidae) do médio Rio Paranapanema, Paraná, Brasil. Rev Bras Zool 2004; 21(2): 207-18. http:// dx.doi.org/10.1590/S0101-81752004000200008

Pariselle A, Euzet L. Systematic revision of dactylogyridean parasites (Monogenea) from cichlid fishes in Africa, the Levant and Madagascar. Zoosystema 2009; 31(4): 849-98. http://dx.doi.org/10.5252/z2009n4a6

Pavanelli GC, Eiras JC, Takemoto RM. Doenças de peixes: profilaxia, diagnóstico e tratamento. 3rd ed. Maringá: EduEM; 2008. 311 p.

Poulin R. Phylogeny, ecology, and the richness of parasite communities in vertebrates. Ecol Monogr 1995; 65(3): 283-302. http://dx.doi. org/10.2307/2937061

Ranzani-Paiva MJT, Felizardo NN, Luque JL. Parasitological and hematological analysis of Nile tilapia Oreochromis niloticus Linnaeus, 1757 from Guarapiranga reservoir, São Paulo State, Brazil. Acta Sci Biol Sci 2005; 27(3): 231-7. http://dx.doi.org/10.4025/actascibiolsci. v27i3.1334

Rohde K, Hayward C, Heap M. Aspects of the ecology of metazoan ectoparasites of marine fishes. Int J Parasitol 1995; 25(8): 945-70. http:// dx.doi.org/10.1016/0020-7519(95)00015-T

Santos EP. Dinâmica de populaçôes aplicada à pesca e piscicultura. São Paulo: HUCITEC/EDUSP; 1978. 129 p.

Tavares-Dias M, Martins ML, Moraes FR. Fauna parasitária de peixes oriundos de "pesque-pague" do município de Franca, São Paulo, Brasil. I. Protozoários. Rev Bras Zool 2001a; 18(S1): 67-79. http://dx.doi. org/10.1590/S0101-81752001000500005

Tavares-Dias M, Moraes FR, Martins ML, Kronka SN. Fauna parasitária de peixes oriundos de "pesque-pague" do município de Franca, São Paulo, Brasil. II. Metazoários. Rev Bras Zool 2001b; 18(1): 81-95. http://dx.doi. org/10.1590/S0101-81752001000500006 
Thatcher VE, Brites-Neto J. Diagnóstico, prevenção e tratamento das enfermidades de peixes neotropicais de água doce. Rev Bras Med Vet 1994; 16(3): 111-28.

Van As JG, Basson L. A further contribution to the taxonomy of the Trichodinidae (Ciliophora: Peritrichia) and a review of the taxonomic status of some fish ectoparasitic trichodinids. Syst Parasitol 1989; 14(3): 157-79. http://dx.doi.org/10.1007/BF02187051

Vargas L, Povh JA, Ribeiro RP, Moreira HLM. Ocorrência de ectoparasitos em tilápias do Nilo (Oreochromis niloticus), de origem tailandesa, em Maringá - Paraná. Arq Ciênc Vet Zool UNIPAR 2000; 3(1): 31-7.
Zaniboni-Filho E. Piscicultura das espécies exóticas de água doce. In: Poli CR, Poli ATB, Andreatta ER, Beltrame E. Aquicultura: experiências brasileiras. Florianópolis: Multitarefa; 2004. p. 309-336.

Zica EOP. Análise parasitológica de peixes em sistemas de tilapicultura em tanques-redes e suas inter-relaçóes com a ictiofauna residente e agregada [Dissertação]. Botucatu: Universidade Estadual Paulista; 2008.

Zuben CJV. Implicaçóes da agregação espacial de parasitas para a dinâmica populacional na interação hospedeiro-parasita. Rev Saúde Pública 1997; 31(5): 523-30. http://dx.doi.org/10.1590/S003489101997000600014 